\title{
ESTUDIOS
}

\section{El objeto de arte como objeto social en Lima virreinal}

\author{
Martha Barriga Tello \\ Universidad Nacional Mayor de San Marcos \\ martha_barriga@yahoo.com.ar

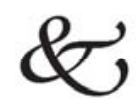

\section{Resumen}

En cualquier sociedad, como en la Lima virreinal, las imágenes que se producen por razones artísticas o religiosas pueden ser interpretadas y consideradas de diversas maneras por los observadores y usuarios. Esto es posible por su carácter abierto, que permite su apropiación para diversos objetivos.

Palabras claves: Arte virreinal, Lima, objeto de arte.

\begin{abstract}
In any society, in this case viceroyalty Lima, art images, produced with artistic or religious intentions, may take different ways in the comprehensive mind of the observers and users. It occurs because its nature is open and can be apropiate in different ways.
\end{abstract}

Key words: Colonial art, Lima, art object.

\section{Efectos en las imágenes}

Sobre su objeto de investigación, la Historia del arte distingue entre la obra producida con intención artística, que es meramente representativa (objeto de arte), y aquella que tiene una intención significativa y destaca por sus cualidades dentro de este amplio grupo (obra de arte). La obra de arte resulta 
del análisis y estudio del sustrato material que constituye el objeto de arte que, por sus cualidades formales, estéticas y significantes resalta su existencia como "fenómeno artístico", en comparación a otras de su espacio tiempo, tanto a las producidas en su momento, incluso por el mismo artista, como a las de etapas anteriores que, se comprobará, que ha superado en soluciones y planteamientos, e igualmente considerando las posteriores sobre las que habría influido e inspirado para lograr nuevas soluciones (Patch 1989:10-12). Esta reflexión se sustenta en todo objeto con intención artística producido en la etapa seleccionada y vinculado a los modos de representación, a las maneras de ver y de pensar que configuraron el imaginario de la época.

La configuración del imaginario virreinal fue un dinámico proceso que fluctuó entre la aceptación y el rechazo; la identificación y la independencia. Construyó, adecuó, modificó y evadió la normativa peninsular elaborada sobre la base de una realidad diferente a la que se desarrollaba en la América hispana. Para expresarse, América utilizó los códigos occidentales impuestos oficialmente y extendidos en todo su territorio, pero mantuvo un proceso de conciliación con los de las culturas ancestrales, profundamente arraigadas en las poblaciones. La interacción de las culturas europea y americana se produjo en todos los habitantes, no fue un proceso unidireccional. Los pueblos actuales de América evidencian y se reconocen por peculiaridades que solamente se explican por las características de las culturas nativas que los habitaron. Son claramente distinguibles, por lo que no puede considerarse a la cultura americana como única, aunque la recorre un eje que enlaza todas las propuestas y por el que es posible identificarla. Como ejemplo, en lo que se refiere a la gestión virreinal, las reacciones ante la legislación peninsular que afectó las manifestaciones creativas y de culto, y se aplicó sin considerar sutilezas e idiosincrasias particulares, fueron peculiares en cada una de las unidades administrativas en las que España tenía organizado el continente.

El pensamiento en el siglo XVIII americano respecto a las obras de arte plástico y arquitectónico estuvo dirigido por el Estado como gran organizador, y las necesidades y propósitos de la Iglesia como principal cliente, de las que derivaron los objetivos específicos del resto de la población en capacidad de contratar a un artista. En términos generales, estilísticamente el Estado establecía las pautas, la Iglesia las interpretaba, la cultura libresca introducía matices previos y posteriores que podían materializarse en las celebraciones públicas, y el resto de la población se apropiaba y reprogramaba las propuestas en obras destinadas a un uso particular.

En el empleo de las imágenes artísticas y/o de religión hay que establecer la iconografía de las devociones promovidas por la Iglesia así como las mejor acogidas por la población, tanto como la conducta que se esperaba se debía te- 
ner ante ellas. Existieron variables respecto a la importancia que se le confirió a la imagen como elemento de culto y a su carácter propedéutico, aspectos que comprometieron tanto a la Iglesia como a los fieles. En este contexto interactivo, la producción de obras de arte que se le vinculaba supuso la adaptación de los artistas a las exigencias de los clientes y, muchas veces, a la formalización de variables surgidas del imaginario popular, antes que de la preceptiva de la Iglesia que se sustentaba en la literatura religiosa. Opciones que con frecuencia se impusieron con la aceptación, y justificación, de la misma Institución. Como resultado, muchas veces la imagen concentró los poderes que se otorgaba a las reliquias, dando lugar a eventos de profunda raigambre popular e identificación regional.

A propósito del culto a las reliquias y sus convenciones, el Concilio de Lima de 1772 en el Título De reliquiis et Veneratione Sanctorum et Processionibus, reafirma las disposiciones tridentinas vinculadas a los restos sagrados, así como insiste en su cumplimiento por parte de los religiosos que estaban en contacto con los fieles,

Por quanto las Cosas Santas santamente deven tratarse, las reliquias siempre estarán colocadas en lugar decente (...) no se expongan a la publica veneración sin que sean antes reconocidas por los Obispos (Concilio de Lima: 1772: Acción III, Libro III, Título VIII, Cap. 1,II).

Se observa específicamente la reiteración de ciertos tópicos, lo que refleja la necesidad de enfrentar problemas aún vigentes. El primer punto está referido al culto a las reliquias, su adecuada exposición pública y la prohibición de que el pueblo accediera a reconocerlas de manera impropia, sobre todo cuando aún no habían pasado por el proceso de verificación y autorización del obispo. Esta norma debió ser una llamada de atención a la entusiasta veneración que se rendía a algunas, que en ocasiones se desbordaba, por incitación del mismo clero (Álvarez 1985).

Otro asunto que se menciona en la legislación llama a reflexión, porque lo encontramos concretado en determinadas medidas extremas que debieron tomar algunas órdenes con el pretexto, o la justificación, de que eran necesarias para paliar los efectos de los desastres sísmicos. El capítulo III del mencionado Concilio de Lima de 1772 se refiere a que

Por respeto que es devido (sic) a las reliquias Agnus, Cruces e Imágenes nunca se pondrán en venta pública de Almoneda. Ni pribadamente (sic) se vendan en más precio que el de el valor del relicario, Urna, metal o materia de su hechura. Entendiendose lo mismo de los Calizes (sic), Patenas, Aras consagradas y ornamentos. Y en quanto (sic) al los Agnus se entienda obserbe (sic) la Constitucion Omni certe del Señor Gregorio XIII (Concilio de Lima de 1772. Acción III, Libro III, Título VIII, Cap. III). 
Poseer reliquias daba importancia a las congregaciones, era un respaldo de autoridad tanto por haberlas recibido como gracia, así como por haber pertenecido a miembros de su comunidad, por lo que existió la preocupación por exponerlas adecuadamente en lugares señalados de los templos, aunque la teatralidad que acompañó estas exhibiciones formó parte del rechazo que se manifestó en la legislación borbónica. Los fieles acudían a visitar los retablos en los que se congregaban las más significativas, guardadas en delicadas, y con frecuencia lujosas urnas. Periódicamente eran expuestas públicamente y llevadas en procesión en medio de gran aparato y respeto.

\section{Reliquias y objetos litúrgicos}

Los objetos considerados como reliquias, ¿en qué medida lo eran de manera permanente y qué tan intangible era su condición? Por la época se produjo un hecho que fue implícitamente avalado por la norma conciliar. Algunas congregaciones pusieron ciertas reliquias en pública oferta junto con otros objetos sagrados, tantos como fuera necesario para cubrir las necesidades inmediatas. Aunque la referencia al traspaso de reliquias suele brindarse en términos de donación piadosa, no se detecta vacilación en la declaración de los religiosos respecto al valor y al uso que debían darle a sus objetos litúrgicos. Por otra parte, la oferta no se dirigió al mercado de los pares, que podría haberse interesado considerando que en teoría compartía los mismos objetivos y pretensiones de quienes se desprendían de ellos, sino que se ofrecieron al sector laico, aquel que conformaban las clases económicamente poderosas convertidas en benefactoras y, a través de este comercio, paralelamente en discretas y autorizadas depredadoras del patrimonio eclesiástico. La situación puede advertirse grave porque muchos de sus miembros estaban vinculados por familia, o por negocios, a las autoridades de la congregación que las vendía. Un ejemplo de esta práctica, no exclusiva de la Orden que mencionaremos, devino a propósito de uno de los más devastadores terremotos en Lima ocurrido el 28 de octubre de 1746. Era Provincial de la Orden de San Agustín el Maestro Pablo Ponce de León (1746-1750), y Prior el Maestro Diego Pacheco. El 18 de noviembre Ponce de León,

reunió a todos en el claustro segundo del convento por no haber otro lugar seguro [26]. Todas las casas [estaban] en el suelo, se maltrató el trapiche y horno de Boca Negra, el mar robó cañaverales, no había con qué mantenerse. Decidióse mandar a la mayoría [de los frailes] a las provincias y quedar pocos para los oficios. Los que quedaran debían irse a vivir al lugar llamado Huaquilla o en las pocas celdas que quedaran del convento y que los alarifes declararan seguras (Monasterio 1908: 27). 
Se optó por esto último y, dada la urgencia por conseguir dinero suficiente para la reconstrucción, se acordó vender la hacienda Jaucachi así como empeñar o vender las alhajas de la iglesia y de la sacristía (Monasterio 1908: 28). El acuerdo fue que las alhajas servirían de garantía para un préstamo de dinero pues se afirmó que, de venderlas o empeñarlas, perderían su valor real. Las sacaron, tasaron y pusieron en una caja para pedir un préstamo equivalente, y así reparar la hacienda Bocanegra (Monasterio 1908:29).

En 1779 estuvieron terminados los arreglos y el convento obtuvo una renta de 41,336 pesos. El Visitador anotó que "se ha reedificado dos veces y ya puede albergar 100 religiosos" (Villarejo: 22). En una segunda oportunidad, el 22 de abril de 1802, el provincial Manuel Azereto (1801-1805), pidió autorización para solicitar un préstamo u otra acción a fin de culminar las obras de la iglesia y encargar un retablo mayor nuevo, porque el otro estaba en ruinas (Monasterio 1908:30). Proponía vender los muchos marcos de plata que calificó "de chafalonía"1 y

la corona de perlas que usaba el santo patriarca el día de su fiesta por faltarle varias perlas y luego le faltarían más y no serviría, para darle otra de plata dorada esmaltada con algunas piedras para mejor duración y lo restante para los fines insinuados (Monasterio 1908:31).

También se proyectó reconstruir los muros del altar de Santa Rita y cubrir otras necesidades. Se observa que los objetos vinculados a las figuras de culto no recibieron de la congregación el respeto que solían otorgarles los fieles. Podía negociarse con ellos sin escrúpulo y para fines prácticos. Pero esta medida no estaba sujeta a sanción porque era respaldada por la norma del Concilio de 1772, Título VIII, capítulo III mencionado antes. La preocupación conciliar no recayó en que se pusieran en venta las piezas, sino en el peligro de sobrevalorarlas: "Ni pribadamente (sic) se vendan en más precio que el de el valor del relicario, Urna, metal o material de su hechura". Se deduce que el mérito artístico del objeto no era considerado en absoluto, no se percibía como factor para el justiprecio, porque se equipara o confunde con el del material con el que estaba trabajado. En consecuencia, la estimación y valoración de las obras de arte, que se podría suponer que lo eran por el hecho de que las Órdenes solían convocar a los mejores artistas del medio para producirlas, posiblemente no superó el afán de demostrar la capacidad de comprometer y obligar a los más destacados para con ella, pues de otra manera se habría mencionado como determinante, o por lo menos en condición equiparable, a su valor tangible.

Esta práctica continuó entre los agustinos. En el siglo XIX, y ante la incertidumbre política de la época postrera del gobierno virreinal, inevitablemente

1 "Objetos inservibles de plata y oro, para fundir" de acuerdo a la RAE, pero con connotación peyorativa en el uso corriente. Sin embargo, en el contexto de la justificación su aplicación fue correcta. 
sufrieron las propiedades y los recursos de la Orden. El 18 de septiembre de 1807 , ante la inminente aparición de barcos ingleses en la costa, el virrey Abascal convocó a la ciudadanía. Debía repararse las murallas y a los agustinos les tocó el baluarte que se "halla junto a la portada de San Jacinto, bajo el número siete y para cuyo reparo su costo no podía bajar de 4, 359 pesos", según el monto estipulado por la tasación y que el convento no podía sufragar (Monasterio 1908:32). Respondiendo a la emergencia, el Definitorio resolvió "vender la plata labrada que fuese menos visible y que menos falta hiciese para los destinos y culto de la Iglesia”. Por las especies numeradas, que no se mencionan ni detallan, se obtuvo 2,271 pesos y real y medio. Sin embargo debió ser importante el número y calidad de las piezas vendidas porque, para suplir su falta en la iglesia matriz, se debió recurrir a los conventos de las provincias (Monasterio 1908: 33). Aquí se evidencia otra contradicción. La congregación decidió disponer de objetos litúrgicos indispensables, que por lo tanto hacían falta porque de otro modo no hubiese sido necesario solicitar su reposición con las de otros conventos, lo que de por sí da cuenta de por lo menos su valor artístico, si obviamos el material de su factura, tanto como que se había transgredido el que fueran los "menos visibles".

En este contexto, existía otra costumbre prohibida, pero que estaba muy difundida. Consistía en raspar las reliquias para ofrecer el resultante como "santo remedio" a quien lo requiriera; o también llevarlas a la casa de los fieles cuando estaban enfermos. El Concilio especificó: "Asimismo con ningún pretexto se roan las reliquias para darlas a los enfermos. Ni las que fuesen insignes se lleven a sus Casas sino de licencia de los Prelados y con la decencia que ellos prescriban" (Concilio Limense 1772: Acción III, Libro III, Título VIII, Cap. IV). En ambas circunstancias no se ofrece como suficiente ayuda la invocación y rogativas al santo, sino que se respaldó e incentivó la necesidad de su presencia física. Con el agravante que, en el primer caso, estaba implícito que los religiosos, y los fieles en consecuencia, consideraban efectiva la función mágica del "polvo de la reliquia", porque no otra cosa podía inferirse de tal práctica. La proximidad de las imágenes a una versión real del sujeto representado también causó problemas y en el mismo sentido, incluso podría entenderse que la tendencia mencionada pudo dirigirse a constituir un sustituto para la necesidad de los fieles de una comprobación física.

\section{Culto a las imágenes. Posición de la Iglesia y de los fieles}

El pensamiento ilustrado cuestionó algunos de los principios básicos de la fe popular que se advierte en las prácticas mencionadas. La alusión a milagros y a otros aspectos comenzó a ser vista con desconfianza, o por lo menos con 
mayor cautela. El Concilio realizado en Lima en 1772 hizo una alusión significativa,

Es el Pulpito (como se acaba de decir) Catedra de la Verdad y lugar destinado a la correpción y enseñanza y en este concepto seria mui ageno a la reverencia y respeto con que devera ser tratado, excitar o proponer en él sátiras jocosidades ni ridiculeces (...) se abstendran de hacerlo los Predicadores y tambien el fixar el tiempo de la Venida del Ante Christo, de predicar milagros o revelaciones no aprovadas y de publicar indulgencias apocrifas o dudosas (...) Y los sermones fúnebres que se formasen en el elogio de las personas que muriesen con credito de Santidad o Virtud no en otra forma se prediquen que presentandolo primero al Ordinario para su reconocimiento y examen (...) (Concilio Limense de 1772: Tratado. De Praedicatione Verbi Dei, Cap. 9).

Es clara la reconvención hacia las expresiones burlonas, cómicas o alarmistas; a recurrir a la imaginación desbordada para convencer; a engañar con documentación apócrifa; y a exceder los límites de la compostura. Recogiendo una tradición que había ido incrementándose en el tiempo, fue señalada la propensión a exagerar que condujo la prédica en el siglo XVIII, especialmente en las zonas rurales donde algunos sacerdotes recurrieron a una escenografía impactante para fustigar a los fieles. En la Relación que escribió el Presbítero Ignacio de Castro para narrar las fiestas celebradas en el Cusco, a propósito de haber sido erigida Real Audiencia en 1787, significativamente opinó acerca de la pertinencia de la reiterada utilización de un suceso calificado tradicionalmente como milagroso, ocurrido en el siglo XVI cuando la rebelión del Inca Manco,

El gran Patrón de las Españas Santiago Apóstol y María santísima se hicieron visibles para este auxilio. Es desgracia que hablemos de estas marabillas en un siglo que se dice ilustrado, quando mas dispuesto a rechazar estas que llama quimeras de una divertida imaginación, ó ilusiones que fomenta la superstición. Más o hemos de negar el asenso a lo que nos dicen otras historias; ó estas Apariciones merecen toda aquella fe humana que necesitamos los hombres (Castro 1978: 34).

En principio, Castro rechaza el que se apelara a este medio en la época de la razón, porque alentaba que se los calificaran de desvaríos y hechicerías, aunque comprendía que podía ser un refugio para la fe. La tendencia oficial ilustrada no auspiciaba, pero tampoco relegaba los problemas alrededor de las creencias populares; los intelectuales ilustrados por su parte entendieron que había asuntos que definir para distanciar cualquier posibilidad de vincularlos a la superstición. Los milagros están estrechamente relacionados con los espacios identificados como escenario de algún hecho sobrenatural, así como con la personificación del protagonista de la acción representado por las imágenes. 
Respecto a éstas, existieron dos preocupaciones que aparecen normadas en el Concilio de Lima de 1772 . Una referida a su aspecto y la otra a su utilización. Se insiste en la impertinencia de algunas formalizaciones. En este momento es significativo que se hiciera hincapié en el hecho que,

En la Iglesia ni en otro lugar se coloquen Imágenes no acostumbradas. Ni se pinten o adornen las de los Santos en traxes estraños, indecentes o deshonestos o de modo que puedan causar en la plebe horror o peligro de herror. Ni se pinten o graven dichas Imágenes o la Santa Cruz en Cajetas, Anillos, Llabes de Reloxes, Alfombras u otras alajas de el uso doméstico ni se coloquen en zaguanes, rincones de cementerios ni otros lugares sórdidos e indecentes. Y en igual conformidad con las hostias en que estén grabadas la Cruz o Imágenes, no se cierren cartas como lo dispone una Constitución Sinodal de este Arzobispado (Concilio Limense de 1772: Acción III, Libro III, Título VIII, Cap. V).

En la norma se intentó impedir que las representaciones sagradas fueran utilizadas en términos que serían más apropiados para un juguete, e igualmente procuró detener la aplicación de los motivos en objetos de uso común, o destinarlos a un uso impertinente. Desde el punto de vista del análisis del sector de los fieles se advierte una situación de depreciación y trivialización, o fetichismo de la imagen sagrada, que implicaría también el despojo de su contenido, su desvinculación con la idea a la que debía aludir. Positivamente, incluso podría interpretarse como una fórmula de familiaridad el convertir a la imagen en una figura próxima, de la que era posible apropiarse, precisamente por su estrecha relación con la vida cotidiana. En cualquiera de los extremos perdía su sentido inicial para cumplir un rol social diverso. La preocupación que revela esta disposición está enmarcada en hechos colaterales que discurren por la misma vía.

Se afirma que la trasgresión de los principios establecidos por la Iglesia en el uso público de la devoción y la imagen, encubría la secularización de las costumbres, en aumento a medida que transcurría el siglo XVIII. Sin embargo, no se trata necesariamente de esto, si se analiza el cambio del pensamiento y los hábitos en la época. La simplificación en los usos que fue incorporándose a la acción cotidiana de la población redujo el sentido de lo ritual, un tanto incentivado por la propia legislación borbónica que propugnaba la vuelta a la naturaleza, a lo sobrio, al decoro y lo racional. Por otra parte, igualmente buscó frenar una práctica proveniente de la misma institución religiosa, más extendida y dramática en el medio rural pero no exclusivamente. Si bien en algunos casos la Iglesia cedió al requerimiento devocional expresado por los fieles, fueron más frecuentes las ocasiones en las que propició, incentivó y hasta obligó para que ellos se encargaran de "vestir" a los santos con elementos costosos y llamativos, lo que inevitablemente secularizaba y frivolizaba la imagen, además 
que los presionó para que engalanaran las capillas, auspiciando rivalidades y competencias entre pueblos, barrios, cofradías y hermandades, condenando a la imagen de devoción que se debía mostrar en el culto a un enfrentamiento político y mundano.

Desde la focalización de la Iglesia, el mismo Título VIII, capítulo V está dirigido a defender el planteamiento ofrecido por la legislación monárquica, que buscó el orden y la disciplina en la práctica religiosa apoyadas en la ideológica ilustrada. En el Capítulo VI se llamó la atención sobre un hecho que había sido aludido en los textos de quienes reprochaban la tendencia que hoy conocemos como "barroca". Este confirma que en el Concilio de Lima fueron denunciados ciertos "abusos", aparentemente ocurridos en el lapso que medió entre el inmediato anterior y este de 1772:

Mediante la noticia que se ha dado en el Concilio de que en cierto tiempo comenzaron a introducirse con pretexto de devoción algunos abusos como el de ponerse en las Iglesias una Cama y en ella la efigie de Christo en ademán de enfermo. El cantarse el Credo el Viernes Santo a la Agonía de Christo y el responso puesto en el Sepulcro; se prohíben si en alguna parte subsistieren y para que no vuelvan a introducirse se descarga a los Párrocos y al Promotor Fiscal en que celen en impedir estas y otras semejantes introducciones (Concilio Limense 1772: Acción III, Libro III, Título VIII, Cap. VI)

Nuevamente, los conciliares se ocupaban de los efectos que devenían de acercar los ritos a lo cotidiano familiar, pero también la acotación alude a la teatralización de un hecho que, auspiciado por los religiosos, probablemente buscó acercar la humanidad de Cristo a los fieles, proclives a la emoción frente a su sufrimiento. No dudamos en la eficacia del recurso, pero gran parte del pensamiento oficial en la segunda mitad del siglo XVIII coincidía en cuestionar estos procedimientos por considerar, no sin sustento, que contribuían a pervertir la vivencia de la fe, especialmente porque era complejo trazar la frontera entre lo adecuado y lo que no lo era. Este tema también fue abordado en el aspecto que comprometía la parafernalia de la procesión. Por otra parte, en un debate pastoral de mediados del siglo $\mathrm{XX}$, a propósito del simbolismo funerario, se hace referencia a una consideración que debió tener el mismo sustento que en el siglo XVIII ...el simbolismo funerario. Quiérase o no, los ritos fúnebres han ido
revistiéndose de formas más o menos expresivas y legítimas. Material-
mente el simbolismo de que tratamos consta de detalles que parecería
lícito desdeñar. Tales son las colgaduras, las flores, los túmulos, las lu-
minarias, etc. Pero como quiera que esos detalles traducen y revelan
decisiones y afirmaciones, llegan a tener importancia considerable. Que-
rámoslo o no, imponen una visión y una concepción determinadas de los

LETRAS 81 (116), 2010 
actos ceremoniales, y son los que más vivamente impresionan al común de las gentes, las cuales suelen sentirse tanto más conmovidas cuánto más carecen de instrucción y de familiaridad con la fe de la Iglesia (Varios Autores 1952: 295).

Parte del problema, que se pretendió solucionar con una norma en el Concilio de 1772, fue no advertir que la costumbre y la necesidad expresiva de la devoción del pueblo, la trascendían. Los trajes "deshonestos", los afeites, los adornos, así como los lugares en los que se colocaban las imágenes, estaban estrechamente relacionados con la identificación que mantenían los fieles con ellas, y que auspiciaban los religiosos al inducir su mayor adorno. Por otra parte, el aspecto de las imágenes en cada época histórica o lugar geográfico es frecuente que guarde relación con el de los pueblos y sus costumbres. La Iglesia en el Perú fue comprensiva en este aspecto porque esa mimetización propició que el culto se arraigara, especialmente cuando comprometió la indumentaria con la que se identificaba cada región. Las imágenes, en la mente de sus usuarios tal vez ajenas a su indeterminación e inmaterialidad, tomaron el lugar de los ancestros, se incorporaron a las comunidades y, como miembros activos, fueron asociadas a las acciones cotidianas del grupo. Hasta este momento existe esa vinculación que las hermana a los devotos y que no perjudica directamente el sentido final del ceremonial oficial.

Por otra parte, el ritual cristiano recurría a una teatralidad que comprometiera la participación de los fieles, conducida por el sacerdote y complementada por su vestuario y el de los participantes, la ornamentación del templo, así como el estricto aparato protocolar, antes y después de las ceremonias más importantes del calendario litúrgico. Los conflictos entre la autoridad civil y la eclesiástica, sobre preeminencias en el protocolo que se produjeron a mediados del siglo XVIII, daban cuenta de la importancia que tenía cumplir ciertas pautas, de caracterizar a los individuos y de respetar los fueros otorgados por la etiqueta a la investidura lo que se traduce, en términos dramáticos, al "rol". Con mayor razón estos aspectos debieron signar el simbolismo protocolar de las imágenes sagradas en la mente popular, hecho que puede comprobarse en algunas secuencias previas de encuentros, visitas o saludos entre imágenes, que forman parte de algunas celebraciones religiosas

La normativa emanada del Concilio de Lima evidencia la importancia que se otorgaba a conducir adecuadamente la presencia de la imagen en la actividad social a través de la legislación, al igual que la orientación de su uso y particularidades formales y de devoción, lo que condujo la política eclesiástica y la actitud de los fieles. 


\section{Tratamiento de las imágenes en las exposiciones públicas}

En este contexto, el Concilio Limense de 1772, además del legislar acerca del culto en el interior del templo, se preocupó de las procesiones y, en ellas, su interés estuvo en las imágenes que, en su opinión, sufrían un tratamiento calificado como irreverente. El Concilio alertaba a los responsables a

que se guarde a las Imágenes la mayor Veneración, sin permitir que las Andas se lleven con tropel ni se paren en las puertas de las Casas y Bodegas, el que lleva la Cruz o Imagen de los Rosarios siempre salgan y anden con la decencia y compostura de vida, impidiendo toda irregularidad (Concilios Limenses: 1772: Acción III, Libro III, Título VIII, Cap. VII).

La procesión, según se deduce de este y del capítulo conciliar siguiente, era una fiesta en la que prevalecía la familiaridad resultado del apoderamiento popular del culto. El que los cargadores detuvieran la imagen en casas y bodegas para la veneración particular, no condice con la acotación de la necesidad que se guardara silencio, que no se atravesara alguien en el camino de la imagen, que se prohibiera la venta de comestibles y licores, o que se acompañara con la indumentaria apropiada

En las Procesiones y rogaciones públicas, que esten mientras pasen cerradas las puertas de las tiendas y Bodegas. Y no transiten ni atrabiesen los Fieles so pretexto alguno por donde pasen. Ni puedan acompañarlas los que se hallen con traje indecente y en todas se guardará el silencio que prebiene Santo Toribio en su Sinodo Diocesana (Concilio Limense 1772: Acción III, Libro III, Título VIII, Cap.1, VIII).

La procesión podía prohibirse si no se guardaban estas pautas, especialmente las que se realizaban de noche durante la Semana Santa, por la preocupación de que degenerara en situaciones inconvenientes. Como prevención, se aconsejaba el ayuno de la Cuaresma,

\begin{abstract}
...uno de los medios que siempre ha reconocido la Iglesia mas eficaces para corregir los movimientos de la carne, sujetar la rebeldía de las pasiones, fortalecer el espíritu contra las tentaciones de sus enemigos y levantar el Corazón de Dios. Pero tanto en el como en los demas que generalmente se observan en el año es demasiada la relajación que se ha introducido por la facilidad con que se suelen dispensar por otros. $Y$ tanta que para reformarla y poner en ella el conveniente remedio La Santidad del Señor Benedicto XIV expidió cinco Bulas que para su observancia se hallan publicadas en los Reynos de España... (Concilio Limense 1772: Acción III, Libro III, Título IX).
\end{abstract}

En España se repetía el problema porque, en este mismo sentido, se condujo la legislación en las disposiciones generales para el reino que pretendieron regular ciertas acciones tildadas de inconvenientes. La transformación se produjo en todo 
el territorio imperial hispano, y no exclusivamente en el ámbito americano. Puede recrearse el conjunto de la procesión, y así también fue percibido por algunos contemporáneos, como más próximo a las libertades posibles en una fiesta carnavalesca que religiosa.

La procesión fue una de las actividades que congregó la mayor atención de las autoridades y de la sociedad virreinales. Como ceremonia pública había adquirido tal magnificencia, que era necesaria la concurrencia de sectores pudientes de la sociedad que estuvieran en condición de solventarla. En el transcurso del siglo XVIII fue mayor la intervención de los particulares, y de los gremios que la convirtieron en una expresión de los cambios en la sociedad estamental. Para éstos en particular, tal como se consigna para otros sectores americanos, la participación bajo el estandarte de su respectiva cofradía, con sus imágenes de devoción, en algunos lugares precedidos por gigantes y tarascas bailando, era fundamental para establecer su presencia social (Tanck de Estrada 1979: 325).

La injerencia del Estado, civil y religioso, que pretendió regular estas manifestaciones festivas y capitalizar sus consecuencias fue causa de conflicto, porque no siempre coincidió con la tendencia formal a la que aspiraban los participantes. La descripción de algunas de ellas permite advertir los sutiles pero sintomáticos cambios en el período de la muestra. Por otra parte era sentir general lo que se menciona de México, que

El desfile del día del Corpus, que se podría caracterizar como una combinación de nuestro primero de mayo, carnaval y procesión religiosa, empezó a perder algo de su alegría y aspecto popular a partir de 1790", [respecto a que] "el virrey...suprimió los gigantes y tarasca como "nada necesarios, incorrespondientes a la devoción y decoro de semejante solemnidad" (Tanck de Estrada, 1979:329).

En diversos lugares de América se insistió en limitar los denominados "excesos" de fiestas como la Semana Santa y el Corpus Christi, ambas especialmente relevantes como manifestaciones populares. En Lima y otras ciudades virreinales las autoridades religiosas se quejaron que en la noche del Jueves Santo se produjera toda suerte de escándalos, más graves por tratarse de una fecha especialmente significativa para la Iglesia. En México se tomó medidas reguladoras en 1789, 1790, 1791, 1793. En las del 18 de marzo de 1794, específicamente se señaló que se debía "exterminar la costumbre o abuso de que salgan armados [los indígenas] en las procesiones de Semana Santa”, disposición que ya se había emitido para otras ceremonias en 1743 y 1756. El 13 de enero de 1756 Francisco Jiménez Caro, provisor de indios del arzobispado de México, había legislado "contra los nescuitiles, danzas y fiesta de los santiaguitos", que fue reiterada por Manuel Joaquín Barrientos el 11 
de febrero de 1769 , cuando ostentaba el mismo cargo, hasta que en 1778 la fiesta de Santiago fue definitivamente prohibida (Gruzinski 1985: 179 y nota 15 y 180$)$.

La corona española en el siglo XVIII cuidó permanentemente de legislar en coherencia a su propuesta de transformación de las costumbres hispanas. En la Península y en América, las normas tuvieron mayor impacto en el ejercicio de gobierno que en las actividades populares. Incluso se advierte que algunos cuerpos del Estado fueron proclives a subvertir aquellas que no se ajustaban a la costumbre. Para entonces, los pueblos americanos compartían la libertad que permitía su lejanía del centro de poder, y aquella que les otorgaban las autoridades que llegaban a gobernarlos. Sin embargo, la necesaria adecuación a ciertos usos y pautas estilísticas, significó variaciones respecto a introducir una mayor simplificación que, finalmente, se reflejó en los usos cotidianos tanto como en las expresiones plásticas. En lo que concierne a las obras de arte, la indeterminación estilística mencionada al inicio, y el hecho que en gran parte el estilo identificado como Barroco presentó etapas sobrias y reguladas, junto con otras de mayor imaginación y libertad formal, que en determinados momentos se caracterizó por una fuerte presencia local, dificulta que pueda establecerse estrictamente una línea divisoria entre obras de arte plástico y de arquitectura que adoptaron o no las pautas borbónicas. En ocasiones pueden encontrarse simultáneamente en un mismo objeto de estudio. En consecuencia, el atenerse a los textos y documentos para verificar y confrontar si la tendencia de cada lugar americano respecto a la normativa ilustrada fue su aplicación, digresión o rebeldía debe focalizarse rigurosamente en los objetos de arte. En ellos debe reconocerse si representaron una opción peculiar y característica que implicó soluciones creativas a un estímulo inevitable tal como, por otra parte, sucedió en la Península. No se niega la originalidad de las manifestaciones artísticas españolas, a pesar que las normas ilustradas fueron tan extrañas en algunas de sus regiones como en el resto del imperio. Tampoco puede ignorarse que las poblaciones americanas, dependientes administrativamente de España, habían tenido tiempo suficiente para desarrollar propuestas privativas a sus circunstancias ante estímulos formales externos e internos, un proceso regular identificado con la creación artística en cualquier tiempo y lugar. En este caso el objeto de arte reflejó en sus múltiples manifestaciones la dinámica de una sociedad en transformación y, progresivamente, más consciente de sus particularidades.

\section{Conclusiones}

En Lima virreinal los actos de la vida cotidiana pública, laica o religiosa estuvieron orientados por fines prácticos en beneficio de cumplir objetivos 
inmediatos, lo que se produjo en el marco general del ambiente de la producción, encargo y valorización de los objetos de arte. Desde la legislación fue permitido ajustar la interpretación de los criterios que guiaron la normativa referida a la imagen y su aplicación. Rol fundamental cumplió la legislación estatal que orientó la producción de objetos de arte, así como la Iglesia como institución tutelar de la ideología religiosa monárquica, que a su vez legisló en paralelo con ella con el afán de brindar un conjunto coherente que dirigiera la espiritualidad de la época y sus manifestaciones. El creador, el cliente y el usuario, aplicaron su propia interpretación ajustando las imágenes a sus aspiraciones, requerimientos, necesidades e interpretación personal y como parte de un colectivo en proceso de transformación. Una circunstancia que igualmente tuvo repercusiones institucionales. En lo referente a la historia del arte limeño, el acercamiento a la percepción general del receptor, que enmarcó la producción, encargo y valorización de objetos de arte, favorece la comprensión del proceso creativo, de su concretización y de su aceptación, Se puede advertir en este proceso el impacto que tuvieron las decisiones públicas en la orientación que debió conducir la producción artística en el periodo virreinal limeño, verificable en los objetos de arte que se produjeron, se auspiciaron y aquellos que influyeron en etapas posteriores.

\section{Referencias bibliográficas}

ÁLVAREZ BARRIENTOS, Joaquín y José Checa Beltrán (1996). El siglo que llaman Ilustrado. Homenaje a Francisco Aguilar Piñal. Madrid, CSI.

AYALA, Manuel Josef de (1989). Diccionario de Gobierno y Legislación de Indias. Tomo VI de ensayadores a funerales. Edición de Milagro de Vas Mingo. Madrid, Ediciones de Cultura Hispánica, Instituto de Cooperación Iberoamericana.

BARRIGA TELLO, Martha (2004). Influencia de la Ilustración borbónica en el arte limeño: siglo XVIII (Antecedentes y aplicación). Lima, Fondo Editorial de la Universidad Nacional Mayor de San Marcos.

BARRIGA TELLO, Martha (2008). "Imágenes de Lima, testimonios de la presencia cultural española en el Virreinato del Perú en el siglo XVIII”. En Barrera, Trinidad (editora) La herencia cultural de España en América. Siglos XVII-XVIII. Madrid / Frankfurt, Universidad de Navarra, Editorial Iberoamericana / Vervuert; p.p.85-106.

CASTRO, Ignacio de (1978). Relación del Cuzco. Prólogo y edición de Carlos Daniel Varcárcel. Lima, Universidad Nacional Mayor de San Marcos, Dirección Universitaria de Bibliotecas y Publicaciones.

CONCILIO DE LIMA 1772. Véase VARGAS UGARTE 1952: Tomo II.

GARCÍA-GALLO, Concepción (1979). Las notas a la recopilación de leyes de Indias, de Salas, Martínez de Rozas y Boix. Estudio, edición e Índices. Madrid, Ediciones Cultura Hispánica del Centro Iberoamericano de Cooperación.

GRUZINSKI, Serge (1985). "La "segunda aculturación": el estado ilustrado y la religiosidad indígena de Nueva España (1775-1800)". Estudios de historia novohispana.

LETRAS 81 (116), 2010 
Universidad Nacional Autónoma de México, Instituto de Investigaciones históricas. Volumen VIII; pp. 175-202.

MONASTERIO, Ignacio, O.S.A.(1908). "Datos para la historia de los agustinos en el Perú". En: Recuerdos de la inauguración del templo de San Agustín de Lima. Lima, Imprenta de E. Moreno.

PATCH, Otto (1989). Historia del arte y metodología. Madrid, Alianza Editorial.

TANCK DE ESTRADA, Dorothy (1979). "La abolición de los gremios". En: FROST, Elsa Cecilia, Michael C. Meyer y Josefina Zoraida Vázquez (compiladores). El trabajo y los trabajadores en la historia de México. México, El Colegio de México y University of Arizona Press; pp. 311-337.

VARGAS UGARTE, Rubén (1952). Concilios Limenses (1551-1772). Tomo II. Lima. 